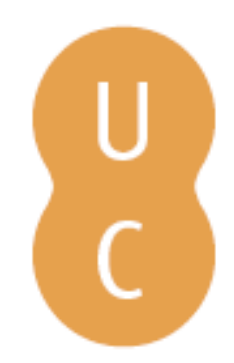

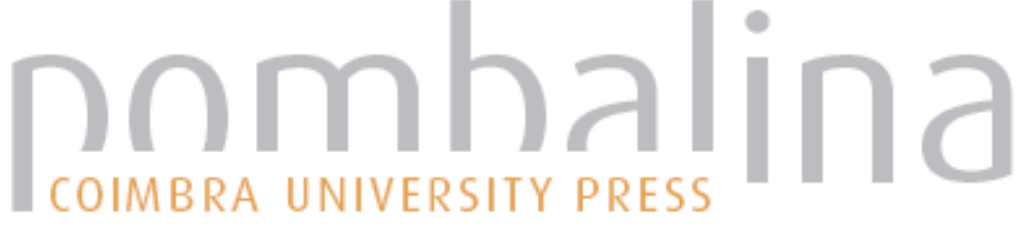

\section{Uncertainty in model predictions of wildland fire rate of spread}

Autor(es): $\quad$ Cruz, Miguel G.; Alexander, Martin E.

Publicado por: Imprensa da Universidade de Coimbra

URL

persistente: URI:http://hdl.handle.net/10316.2/34150

DOI: $\quad$ DOI:http://dx.doi.org/10.14195/978-989-26-0884-6_54

Accessed : $\quad$ 26-Apr-2023 14:52:27

A navegação consulta e descarregamento dos títulos inseridos nas Bibliotecas Digitais UC Digitalis, UC Pombalina e UC Impactum, pressupõem a aceitação plena e sem reservas dos Termos e Condições de Uso destas Bibliotecas Digitais, disponíveis em https://digitalis.uc.pt/pt-pt/termos.

Conforme exposto nos referidos Termos e Condições de Uso, o descarregamento de títulos de acesso restrito requer uma licença válida de autorização devendo o utilizador aceder ao(s) documento(s) a partir de um endereço de IP da instituição detentora da supramencionada licença.

Ao utilizador é apenas permitido o descarregamento para uso pessoal, pelo que o emprego do(s) título(s) descarregado(s) para outro fim, designadamente comercial, carece de autorização do respetivo autor ou editor da obra.

Na medida em que todas as obras da UC Digitalis se encontram protegidas pelo Código do Direito de Autor e Direitos Conexos e demais legislação aplicável, toda a cópia, parcial ou total, deste documento, nos casos em que é legalmente admitida, deverá conter ou fazer-se acompanhar por este aviso.

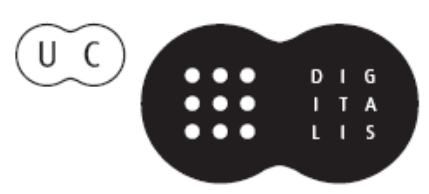




\section{ADVANCES IN}

Forest Fire

\section{RESEARCH}

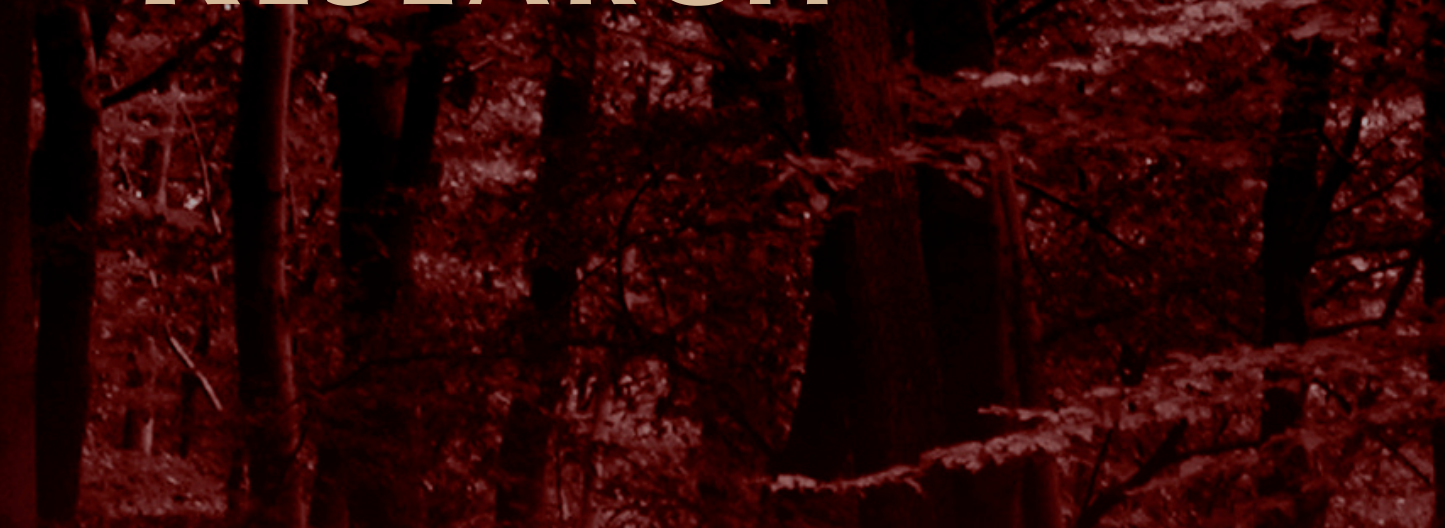

\section{DOMINGOS XAVIER VIEGAS}

\section{EDITOR}




\title{
Uncertainty in model predictions of wildland fire rate of spread
}

\author{
Miguel G. Cruz ${ }^{\mathrm{a}}$, Martin E. Alexander ${ }^{\mathrm{b}}$ \\ ${ }^{a}$ Bushfire Dynamics and Applications, CSIRO Land and Water, \\ GPO Box 1700, Canberra, ACT 2601, Australia, Miguel.cruz@,csiro.au \\ ${ }^{b}$ Department of Renewable Resources and Alberta School of Forest Science and Management, \\ University of Alberta,Edmonton, Alberta, Canada T6G2H1, mea2@telus.net
}

\begin{abstract}
This paper highlights the results obtained from a comprehensive survey recently published by the authors on the error statistics associated with studies that have used independent data derived from field observations of wildfires, prescribed fires and experimental fires to evaluate the performance of 13 models used operationally to predict head fire rate of spread. Answers to the following kinds of questions were sought:

- How accurately can one expect to predict the spread rate of wildland fires with currently available models?

- Can models based on experimental fire data be used to predict wildfire behaviour?

- Are wildfires inherently more difficult to predict the spread rates of than prescribed fires or crown fires compared to surface fires?

- How realistic is it to expect an exact prediction of rate of fire spread?

- What is an acceptable error for rate of fire spread models?
\end{abstract}

A total of 49 studies, comprising 1278 paired observations vs. model predictions of fire spread rates for four forest fuel types (hardwood, mixedwood, conifer, eucalypt) and three non-canopied fuel types (grassland, shrubland, logging slash) from four continents (North America, Australia, Europe, Africa) were assembled. The answers to the five questions asked above are as follows:

- Mean absolute percent error varied between 20 and 310\% and was homogeneous across fuel type groups. Slightly more than half of the evaluation datasets had mean absolute percent errors between 51 and 75 percent. Under-prediction bias was prevalent in 75 percent of the case 49 datasets analysed.

- Empirical-based fire spread rate models founded on solid field observations and well accepted functional forms, can adequately predict rates of fire spread well outside of the bounds of the data used in their development.

- There was no evidence to be found that predicting the rates of spread of wildfires was any more difficult than that of prescribed fires. Spread rates of crown fires were no more difficult to predict that surface fires.

- Only three percent (i.e. 35 out of 1278) of model predictions were considered to be exact (i.e. \pm 2.5 percent of the observed rate of fire spread).

- $\mathrm{A} \pm 35$ percent error interval constitutes a reasonable standard for model adequacy.

Keywords: fire spread models; fire behaviour; error; surface fires; crown fires; wildfires; prescribed fires.

\section{Introduction}

There are a variety of aspects associated with the subject of wildland fire behaviour (Scott et al. 2014) and reasons to increase our knowledge on the subject through continuing research and improvements in operational practice (Cruz et al. 2014a,b). However, if one could boil down the whole science of wildland fire behaviour to its most practical essence, it might very well be to provide fire operations personnel with a decent estimate of just how fast a free-burning fire (Figure 1), either of planned or of unplanned origin, would likely spread based on the prevailing fire environment conditions (Van Wagner 1985). 
This paper highlights the study undertaken by Cruz and Alexander (2013) that addressed the following kinds of questions:

- How accurately can one expect to predict the spread rate of wildland fires with currently available models?

- Can models based on experimental fire data be used to predict wildfire behaviour?

- Are wildfires inherently more difficult to predict than prescribed fires or crown fires compared to surface fires?

- How realistic is it to expect an exact prediction of rate of fire spread?

- What is an acceptable error for fire spread models?

It is fully recognized that the degree of accuracy in model predictions of rate of spread in wildland fires is dependent on the model's applicability to a given situation, the validity of the model's relationships, and the reliability of the model input data (Alexander and Cruz 2013b).

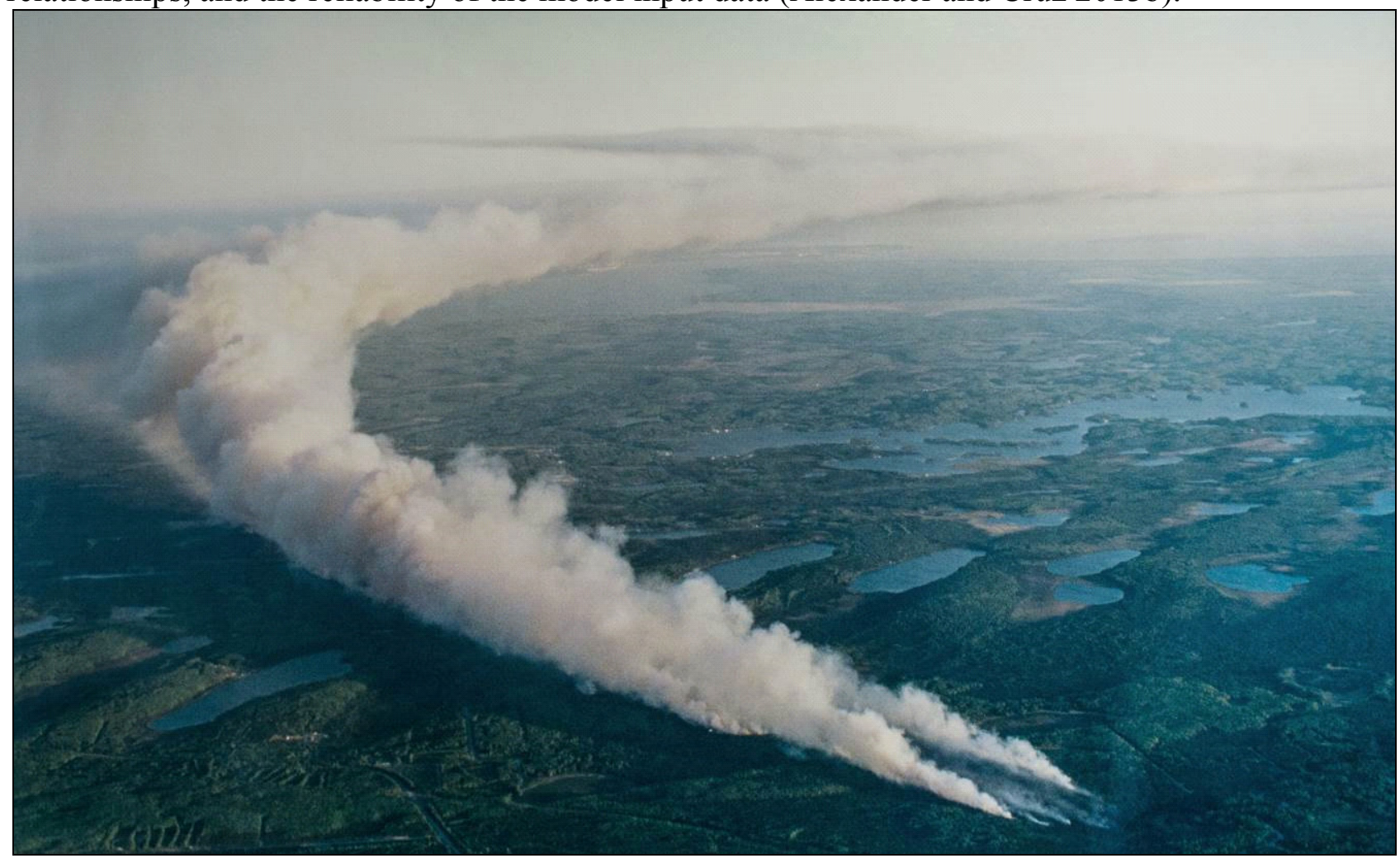

Figure 1. Photo of the Millers Reach \#2 Fire near Anchorage, Alaska, during its major run on June 3, 1996 that involved extensive crowning in black spruce forests. Photo by: Anne Raup, Anchorage Daily News. For further information on this wildfire, see Hufford et al. (1998).

\section{Methods}

\subsection{Compilation of datasets}

In order to address the questions poised in the Introduction, a comprehensive effort was made to locate as many evaluation studies of rate of fire spread rate model performance in the literature as possible. The sources included:

- Scientific peer-reviewed journal articles

- Conference and workshop papers

- Technical reports from government agencies

- Post-graduate university theses 
The principal requirements for inclusion in the analyses were that the evaluation data be (i) collected on outdoor experimental fires, operational prescribed fires and (or) wildfires, involving a "line fire" pattern similar to that observed on the head of a free-burning wildfire (Figure 1), as opposed to striphead fires or point-source fire(s) (e.g. Sapsis and Kauffman 1991; Jupen et al. 2013) and (ii) that the dataset could not have been used in the model development (i.e. completely independent observational data) as Albini and Stocks (1986) did in their analysis. For example, Cruz et al. (2005) used the datasets of Alexander et al. 1991, Stocks et al. (2004) and Alexander et al. (2006) to test their crown fire rate of spread model.

Experimental fires carried out in fuelbeds or with head-fire widths judged too narrow to yield realistic pseudo-steady state rates of spread were excluded (e.g. Neuenschwander 1980; Schimmel and Granström 1997). This also included laboratory studies (e.g. Weise and Biging 1997; Menage et al. 2012). To ensure that each study included in the analysis had sufficient data to discern model adequacy for the particular fuel type and burning conditions, we restricted the analysis to studies that had at least five paired observations. Thus, studies like Brown (1982), Pickford et al. (1992) and Fogarty et al. (1997), for example, were excluded from the analysis. Finally, studies where model outputs were not fully independent, as a result of investigators fine tuning model predictions in relation to the observed rates of fire spread (e.g. Woodall 1998; Beavers 2001), were also not selected for analysis.

It was readily acknowledged that the data quality between studies would vary, especially between data obtained from experimental burning programs versus wildfire monitoring. Experimental fire studies are characterized by detailed sampling of fuel structure, weather and fire behaviour (e.g. Everson et al. 1985; Alexander et al. 1991; Stocks et al. 2004) whereas observations associated with wildfires tend to rely on broad assumptions regarding fuels and representativeness of weather data (e.g. Fogarty et al. 1997; Alexander et al. 2013).

\subsection{Calculation of statistics}

Error statistics on the rate of fire spread observations versus predictions were calculated for each of the model performance studies that qualified for inclusion. These included the root mean square error (RMSE), the mean absolute error (MAE), the mean absolute percent error (MAPE), and the mean bias error (MBE) as described by Willmott (1982). In most cases, these error statistics were not reported in the studies that we examined so it became necessary to compute them from the data contained in the associated publication or by contacting the study investigators directly for the data pairs.

The percentages of exact, under- and over-predictions were also calculated. To our knowledge, a definition for what constitutes an exact model prediction does not exist. Thus, for the purposes of this study, we elected to consider an exact model prediction as one where the error was less then \pm 2.5 percent of the observed rate of fire spread.

\section{Results}

\subsection{Assembled database}

Our extensive search for evaluation studies of rate of fire spread model performance resulted in the compilation of 49 suitable cases. At least two studies were overlooked, one consisting of eight lowintensity experimental fires (with spread rates less than $1.5 \mathrm{~m} / \mathrm{min}$ ) in an Australian eucalypt forest (Davis 1976) and a second one involving 28 observations (with spread rates of 1.0 to $89 \mathrm{~m} / \mathrm{min}$ ) garnered from a single wildfire in southern California chaparral (Weise and Fujioka 1998). The number $(n)$ of studies by geographic distribution were as follows:

- Africa $(n=3)$

- Australia $(n=14)$

- Europe $(n=3)$

- North America (i.e. Canada and US; $n=29$ ) 
The combined database ended up amounting to a total of 1278 individual observed rate of fire spread observation - model prediction pairs. This included three types of data (Figure 2):

- Experimental fires $(n=892)$

- Operational prescribed fires $(n=182)$

- Wildfires $(n=204)$

The data encompassed a wide range in fire behaviour and fire propagation regime types, including low- to high-intensity surface fires in both canopied and non-canopied fuel complexes as well as passive and active crown fires (Van Wagner 1977) in several forest and other vegetation types that are prone to crowning (Table 1 and Figure 3). Seven broad fuel type groups could be identified in the 49 studies (Figures 4 and 5):

- Grasslands $(n=6)$

- Shrublands $(n=9)$

- Logging slash $(n=3)$

- Conifer forest $(n=17)$

- Hardwood forest $(n=3)$

- Mixedwood forest $(n=2)$

- Eucalypt forest $(n=9)$

All of the studies involved either empirical $(n=11)$ or semi-empirical rate of fire spread models $(n=$ 2 ). The lack of any physics-based models involvement simply reflects the fact that any performance evaluation studies carried out to date with these type of models has involved four or less paired cases of observation and model prediction (Alexander and Cruz 2013a).

Table 1. Sample size, range in rate of fire spread (ROS), and summary of error statistics by type of fire involved in the 1278 pairs garnered from the 49 comparison studies as compiled by Cruz and Alexander (2013)

\begin{tabular}{|c|c|c|c|c|c|c|c|c|c|}
\hline \multirow[b]{2}{*}{ Type of fire } & \multirow[b]{2}{*}{$\begin{array}{c}\text { No. } \\
\text { of } \\
\text { fires }\end{array}$} & \multirow[b]{2}{*}{$\begin{array}{l}\text { ROS range } \\
(\mathrm{m} / \mathrm{min})\end{array}$} & \multirow[b]{2}{*}{$\begin{array}{c}\text { Exact } \\
\text { predictions }\end{array}$} & \multicolumn{3}{|c|}{ Under-predictions } & \multicolumn{3}{|c|}{ Over-predictions } \\
\hline & & & & $\begin{array}{l}\text { No. } \\
\text { of } \\
\text { fires }\end{array}$ & $\begin{array}{c}\text { Mean } \\
\text { MAPE } \\
(\%)\end{array}$ & $\begin{array}{l}\text { Standard } \\
\text { deviation }\end{array}$ & $\begin{array}{c}\text { No. } \\
\text { of } \\
\text { fires }\end{array}$ & $\begin{array}{c}\text { Mean } \\
\text { MAPE } \\
(\%)\end{array}$ & $\begin{array}{l}\text { Standard } \\
\text { deviation }\end{array}$ \\
\hline Surfa & 1009 & $0.1-150.9$ & 32 & 631 & $48 \%$ & $25 \%$ & 346 & $99 \%$ & $137 \%$ \\
\hline Crown fires & 269 & $3.4-175$ & 3 & 180 & $51 \%$ & $22 \%$ & 86 & $61 \%$ & $63 \%$ \\
\hline
\end{tabular}

\subsection{Mean absolute percent errors}

The mean absolute percent error (MAPE) is a very popular measure of the accuracy of a predictive model or system. It represents the summed differences between the individual predicted versus observed values divided by the observed value; multiplying it by 100 makes it a percentage error. MAPE values were found to vary between 20 and 310 percent and were homogeneous across the seven fuel type groups. The distribution of model comparisons by MAPE classes were as follows:

- 30 percent or less $(n=7)$

- 31 to 50 percent $(n=9)$

- 51 to 75 percent $(n=26)$

- 76 percent and greater $(n=7)$ 


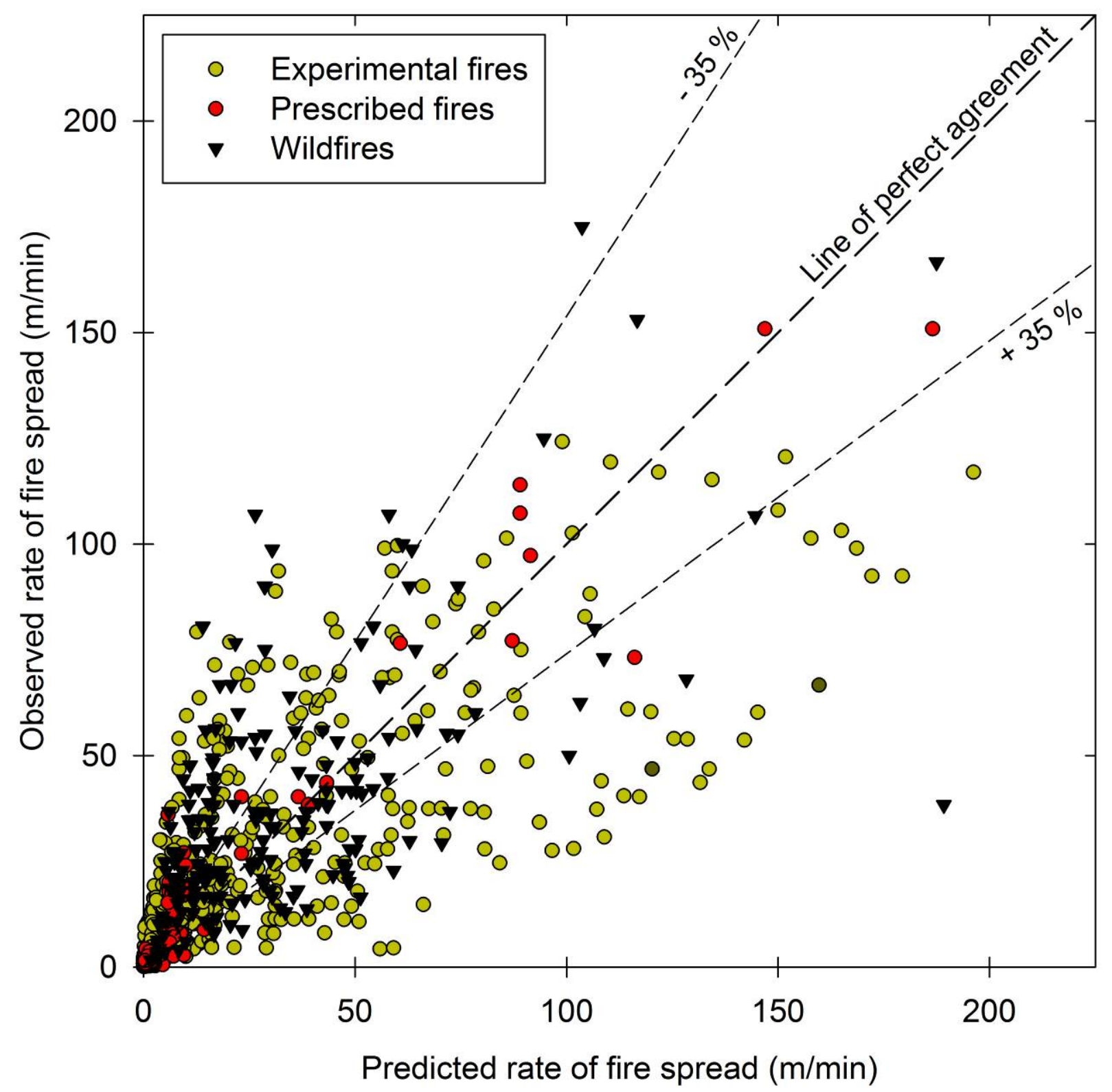

Figure 2. Observed rates of fire spread versus model predictions by type of data involved in the 1278 pairs garnered from the 49 comparison studies as compiled by Cruz and Alexander (2013). The two dashed lines around the line of perfect agreement indicate the \pm 35 percent error interval.

The lowest errors (i.e., from 20 to 30 percent) were associated with seven studies involving experimental fires and prescribed fires where fuel and weather inputs would have been measured onsite. For comparisons dealing exclusively with wildfires, errors varied from 33 to 59 percent. 


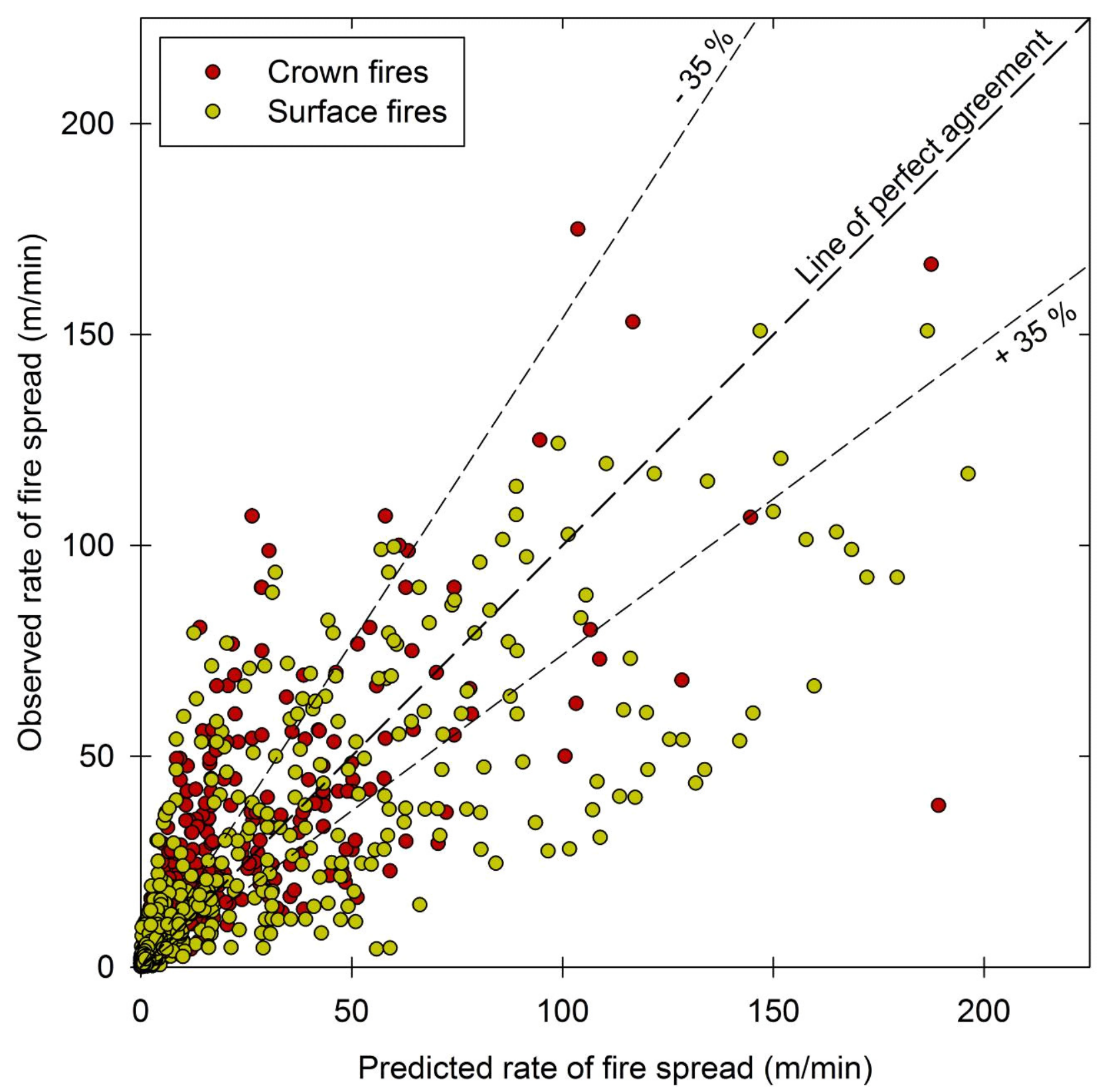

Figure 3. Observed rates of fire spread versus model predictions by type of fire involved in the 1278 pairs garnered from the 49 comparison studies as compiled by Cruz and Alexander (2013). The two dashed lines around the line of perfect agreement indicate the \pm 35 percent error interval.

\section{Discussion}

\subsection{How accurately can one expect to predict the spread rate of wildland fires with currently available models?}

No significant differences were found for under- and over-prediction errors by the type of data source (Figure 2). However, it was found that the rate of fire spread models examined under-prediction occurred in 818 of the 1278 model comparisons (i.e. 64 percent).

Although the range in rate of fire spread in the independent wildfire datasets was much higher than in the datasets used in model development, the model structure allowed for consistent predictions over the full range of observed fire behaviour. In most cases, under-prediction bias was small. There were, 
however, combinations of model and fuel type that resulted in a predominant, if not total, underprediction bias. This included, for example, Rothermel's (1972) surface fire rate of spread model in conifer forests and in logging slash, and both the Rothermel (1991) and Schaaf et al. (2007) crown fire rate of spread models.

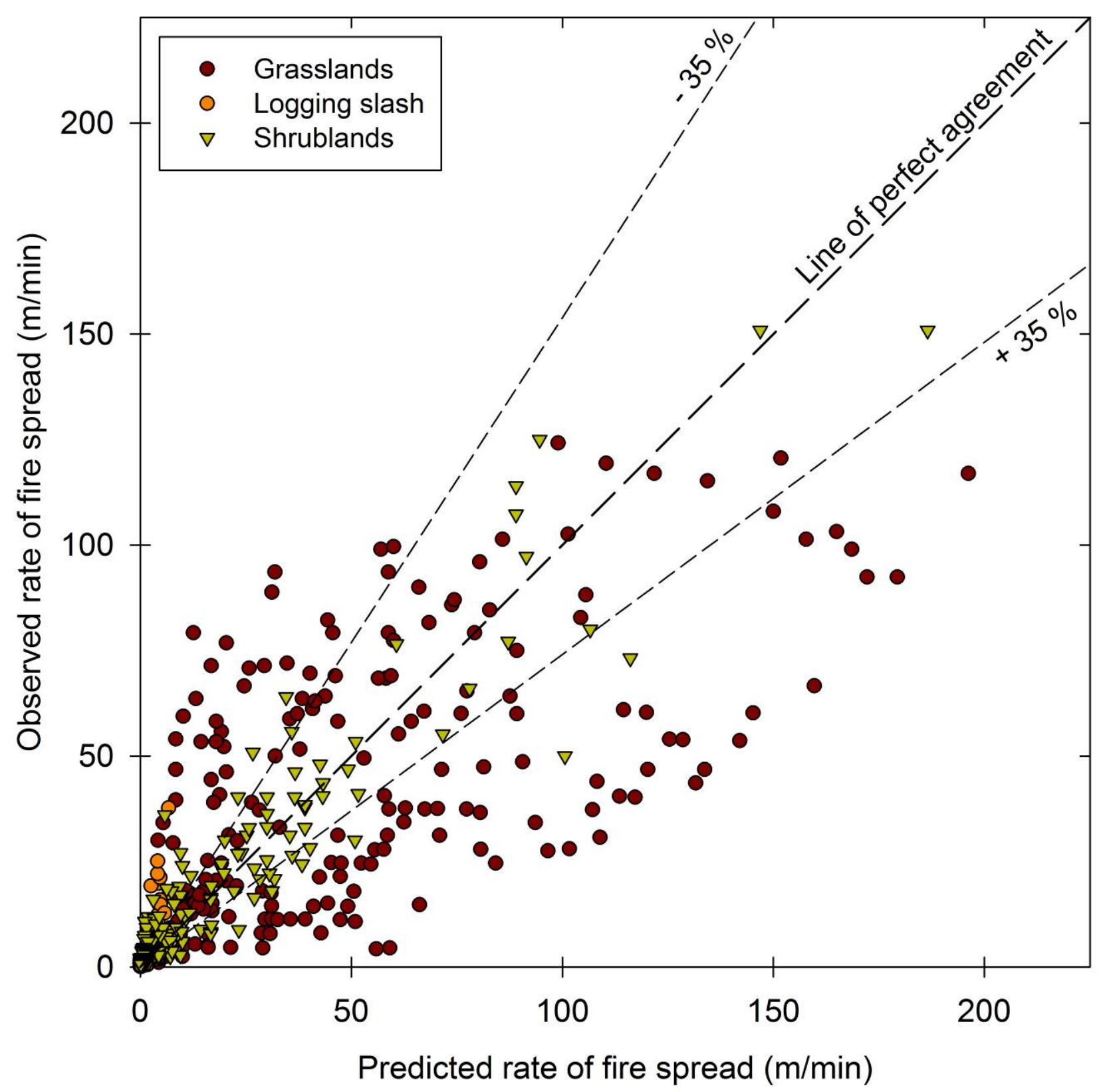

Figure 4. Observed rates of fire spread versus model predictions for non-canopied fuel types (grassland, shrubland and logging slash) involved in the 441 pairs garnered from the 17 comparison studies as compiled by Cruz and Alexander (2013). The two dashed lines around the line of perfect agreement indicate the \pm 35 percent error interval. 


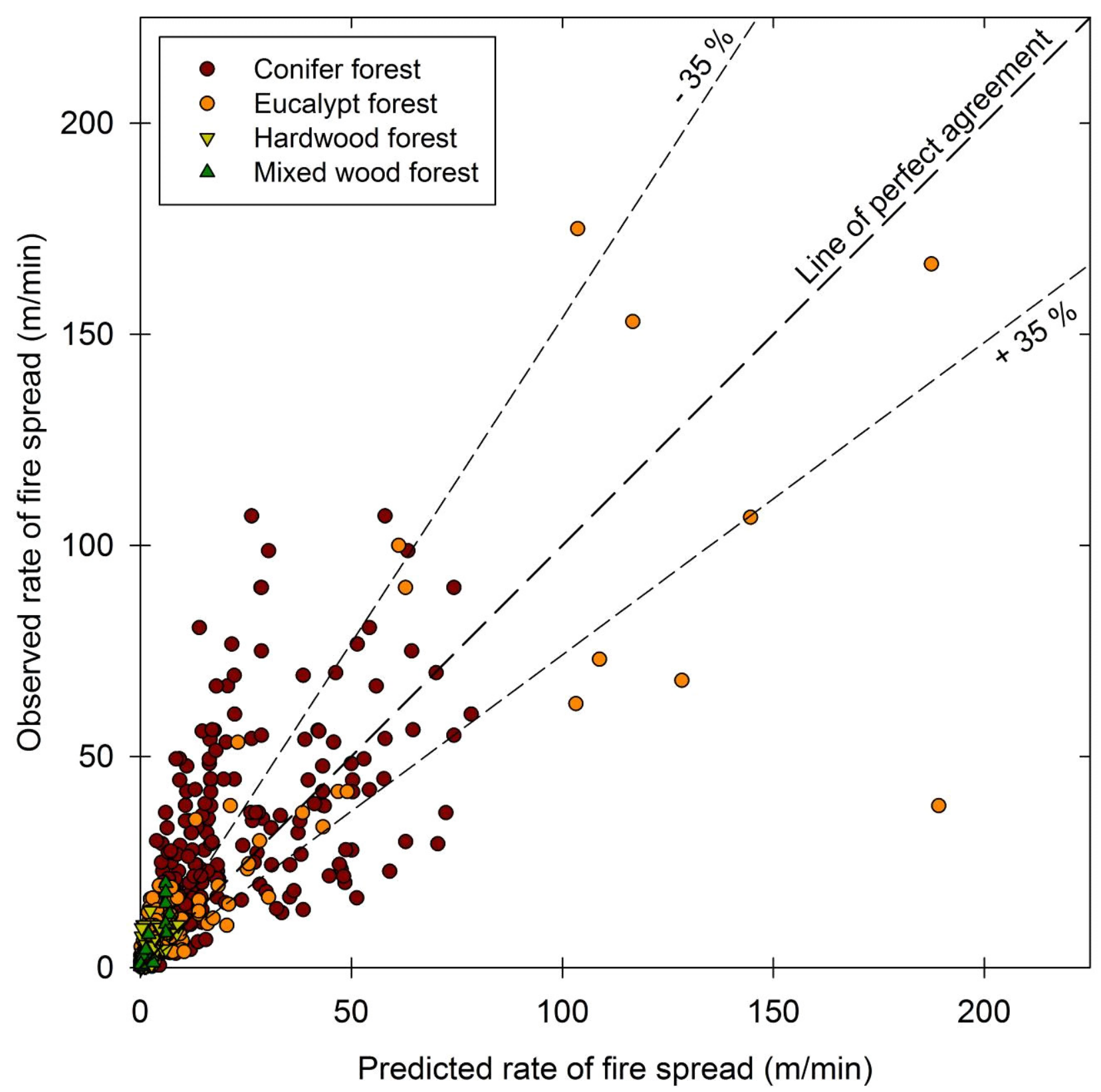

Figure 5. Observed rates of fire spread versus model predictions for forest canopied fuel types (hardwood forest, mixedwood forest, conifer forest and eucalypt forest) involved in the 837 pairs garnered from the 32 comparison studies as compiled by Cruz and Alexander (2013). The two dashed lines around the line of perfect agreement indicate the \pm 35 percent error interval.

\subsection{Can models based on experimental fire data be used to predict wildfire behaviour?}

Only two of the 13 rate of fire spread models considered in the study were separately evaluated against both experimental fire and wildfire datasets. This included the models developed by Cruz et al. (2005) and Cheney et al. (2012) where the MAPE values for the experimental fires where 26 and 35 percent, respectively. In turn, the Cruz et al. (2005) model yielded MAPE values of 46 and 52 percent for two separate wildfire datasets, while for the Cheney et al. (2012) model, the MAPE was 54 percent.

The increase in MAPE is expected given the uncertain nature of the exact environmental conditions associated with the wildfires. In these evaluations against wildfire data, both the Cruz et al. (2005) model, which is the basis for the Crown Fire Initiation and Spread (CFIS) system (Alexander et al. 
2006), and the Cheney et al. (2012) model were extended well beyond the bounds of dead fuel moisture content, wind speed, and rate of fire spread used in their development. This implies that the underlying functional relationships in these models are valid for far drier and windier wildfire conditions than those involved in the model development, a conclusion that Fernandes (2014) has also recently shown to be valid.

\subsection{Are wildfires inherently more difficult to predict the spread rates of than prescribed fires or crown fires compared to surface fires?}

Examination of error statistics revealed no discernible difference in the ability to predict wildfire rates of spread from those associated with prescribed fires.

Some fire researchers have contended on the basis of the dynamic nature of crown fires that their behaviour is more unpredictable than that of surface fires (e.g. Cohen et al. 2006). However, according to the error statistics computed for surface and crown fires, there appears to be no differences, at least with respect to predicting rate of fire spread (Table 1). In fact, the highest MAPE values were obtained for surface fires rather than for crown fires.

\subsection{How realistic is it to expect an exact prediction of rate of fire spread?}

On the basis of the 49 studies and 1278 paired observations versus model predictions complied and analyzed, we found that the concept of an exact prediction of rate of fire spread to be an elusive one. Only three percent of the predictions (i.e. 35 out of 1278) were considered to be exact. It thus appears that the only certainty about rate of fire spread predictions is that it is extremely unlikely that a prediction will exactly match the observed fire spread rate.

\subsection{What is an acceptable error for fire spread models?}

McArthur (1977) considered that the fire danger meters he had developed for Australian grasslands and eucalypt forests could predict rate of fire spread and other fire behaviour characteristics to within \pm 20 percent of the actual observed value. Kilinc et al. (2013) have recently shown this assertion to have been quite optimistic.

From a statistical standpoint one might think that a \pm 1.0 standard deviation as a reasonable measure for an acceptable error. Assuming a normal distribution, such a quantity corresponds to a 34.1 percent departure from the mean. Richard C. Rothermel (USDA Forest Service retired, personal communication, 2012) was to remark to the authors that "I do like your suggestion of one standard deviation being used as a criteria for evaluating what can be expected in model prediction". This error threshold is also consistent with the average errors associated with several experimental field studies of fire behaviour.

According to the present study only two out of the 49 model performance studies (i.e. 4 percent) had a MAPE of 20 percent and no study had any less of a value. Eight of the 49 model comparisons (i.e. 17 percent) had a MAPE equal to or less than 35 percent suggesting that this could constitute a realistic benchmark by which to judge good model performance when accurate input data is available. On the basis of this outcome and the aforementioned considerations, it would appear that a \pm 35 percent error would constitute a reasonable and conservative standard for fire spread rate model performance.

Of course a \pm 35 percent error benchmark is only deemed applicable to research studies. In operational practice, given the uncertainty in the estimation of the input data, often times involving large spatial (e.g. $>1000$ ha) and temporal (i.e. from one to several hours) scales, would understandably, result in wider error intervals.

\section{Conclusions}

A comprehensive survey of the error statistics associated with evaluation studies of rate of fire spread models was undertaken by Cruz and Alexander (2013) in order to gauge the general predictive ability 
of such models. This has led to new insights into some of the uncertainties associated with model predictions of free-burning wildland fire behaviour. This survey has also accordingly highlighted the importance of model evaluation (Cruz et al. 2003) based on independent datasets and encouraged others to do so (e.g. Anderson et al. 2014 in review).

It is worth noting that our evaluation study focused on models of forward or head fire rate of spread (i.e. in one dimension). More recent studies evaluating spatially explicit fire propagation models have relied on a distinct number of metrics to quantify the error associated with wildland fire growth simulations (e.g. Filippi et al. 2014a,b). These were not considered in our analysis as the spatial outputs are only partially dependent on the fire spread rate.

\section{Acknowledgment}

This paper is a contribution of Joint Fire Science Program Project JFSP 09-S-03-1.

\section{References}

Ablini FA, Stocks BJ (1986) Predicted and observed rates of spread of crown fires in immature jack pine. Combustion Science and Technology 48, 65-76.

Alexander ME, Cruz MG (2006) Evaluating a model for predicting active crown fire rate of spread using wildfire observations. Canadian Journal of Forest Research 36, 3015-3028.

Alexander ME, Cruz, MG (2013a) Are the applications of wildland fire behaviour models getting ahead of their evaluation again? Environmental Modelling \& Software 41, 65-71.

Alexander ME, Cruz MG (2013b) Limitations on the accuracy of model predictions of wildland fire behaviour: a state-of-the-knowledge overview. Forestry Chronicle 89, 370-381.

Alexander ME, Cruz MG, Lopes AMG (2006) CFIS: a software tool for simulating crown fire initiation and spread. In 'Proceedings of $5^{\text {th }}$ International Conference on Forest Fire Research', 27 30 November 2006, Figueira da Foz, Portugal. (Ed. DX Viegas) (CD-ROM) (Elsevier BV: Amsterdam, the Netherlands)

Alexander ME, Heathcott MJ, Schwanke RL (2013) 'Fire behaviour case study of two early winter grass fires in southern Alberta, 27 November 2011.' (Partners in Protection Association: Edmonton, $\mathrm{AB})$

Alexander ME, Stocks BJ, Lawson BD (1991) Fire behavior in black spruce-lichen woodland: the Porter Lake Project. Forestry Canada, Northern Forestry Centre, Information Report NOR-X-310. (Edmonton, AB)

Anderson WR, Cruz MG, Fernandes PM, McCaw L, Vega JA, Bradstock RA, Fogarty L, Gould J, McCarthy G, Marsden-Smedley JB, Matthews S, Mattingley G, Pearce G, van Wilgen BW (2014) A model for predicting fire spread in shrublands. In review.

Beavers AM (2001) Creation and validation of a custom fuel model representing mature Panicum maximum (Guinea grass). Colorado State University, The Center for Environmental Management of Military Lands, CEMMIL TPS 01-12. (Fort Collins, CO)

Brown JK (1982) Fuel and fire behavior in big sagebrush. USDA Forest Service, Intermountain Forest and Range Experiment Station General Technical Report INT-290. (Ogden, UT)

Cheney NP, Gould JS, McCaw WL, Anderson WR (2012) Predicting fire behaviour in dry eucalypt forest in southern Australia. Forest Ecology and Management 280, 120-131.

Cohen JD, Finney MA, Yedinak KM (2006) Active spreading crown fire characteristics: implications for modeling. In 'Proceedings of 5th International Conference on Forest Fire Research', 27-30 November 2006, Figueira da Foz, Portugal. (Ed. DX Viegas) (CD-ROM) (Elsevier BV: Amsterdam, the Netherlands)

Cruz MG, Alexander ME (2013) Uncertainty associated with model predictions of surface and crown fire rates of spread. Environmental Modelling \& Software 47, 16-28. 
Cruz MG, Alexander ME, Wakimoto RH (2003) Definition of a fire behavior model evaluation protocol: a case study application to crown fire behavior models. In 'Fire, Fuel Treatments and Ecological Restoration: Conference Proceedings', 16-18 April 2002, Fort Collins, CO. (Tech Eds PN Omi, JA Joyce) USDA Forest Service, Rocky Mountain Research Station, Proceedings RMRSP-29, pp 49-67. (Fort Collins, CO)

Cruz MG, Alexander ME, Wakimoto RH (2005) Development and testing of models for predicting crown fire rate of spread in conifer forest stands. Canadian Journal of Forest Research 35, 16261639.

Cruz MG, Sullivan AL, Alexander ME (2014a) Fire behaviour knowledge in Australia: Knowledge gaps and Fire Behaviour Analyst (FBAN) training revision plan. CSIRO Ecosystems Sciences and CSIRO Digital Productivity and Services Flagship, Client Report No. EP145697. (Canberra, ACT)

Cruz MG, Sullivan AL, Leonard R, Malkin S, Matthews S, Gould JS, McCaw WL, Alexander ME (2014b) Fire behaviour knowledge in Australia: a synthesis of disciplinary and stakeholder knowledge on fire spread prediction capability and application. CSIRO Ecosystems Sciences and CSIRO Digital Productivity and Services Flagship, Client Report No. EP145189. (Canberra, ACT)

Davis KM (1976) Behaviour and effects of fire during mild weather. CSIRO Division of Forest Research, Internal Report No. 3. (Canberra, ACT)

Everson TM, Smith FR, Everson CS (1985) Characteristics of fire behaviour in the montane grasslands of Natal. Journal of the Grassland Society of Southern Africa 2(3), 13-21.

Fernandes PM (2014) Upscaling the estimation of surface-fire rate of spread in maritime pine (Pinus pinaster Ait.) forest. iForest 7, 123-125.

Filippi J-B, Mallet V, Nader B (2014a) Representation and evaluation of wildfire propagation simulations. International Journal of Wildland Fire 23, 46-57.

Filippi J-B, Mallet V, Nader B (2014b) Evaluation of forest fire models on a large observation database. Natural Hazards and Earth System Sciences Discussion 2, 3219-3249.

Fogarty LG, Jackson AF, Lindsay WT (1997) Fie behaviour, suppression and lessons from the Berwick Forest Fire of 26 November 1995. New Zealand Forest Research Institute, FRI Bulletin No. 197, Forest and Rural Scientific and Technical Series Report No. 3. (Rotorua, New Zealand)

Hufford GL, Kelley HL, Sparkman W (1998) Use of real-time multisatellite and radar data to support forest fire management. Weather Forecasting 13, 592-605.

Junpen A, Garivaita S, Bonneta S, Pongpullponsakc A (2013) Fire spread prediction for deciduous forest fires in northern Thailand. ScienceAsia 39, 535-545

Kilinc M, Anderson W, Price B, McCaw L (2013) Testing the performance of Australian grassland and forest fire spread models. Research poster presented at $10^{\text {th }}$ Annual Bushfire Cooperative Research Centre Conference, Melbourne, Victoria, 2 September 2013. Available at: http://www.bushfirecrc.com/sites/default/files/managed/resource/72_depi_musa_kilinc.pdf

McArthur AG (1977) Fire danger rating systems. Food and Agriculture Organization of United Nations, FAO Document FO: FFM/77/3-01. (Rome, Italy)

Menage D, Chetehouna K, Mell WE (2012) Numerical simulations of fire spread in a Pinus pinaster needles fuel bed. In '6th European Thermal Sciences Conference', 4-7 September 2012, Poitiers, France. (Eds D Petit, NC Le) (Société française de thermique: Paris)

Neuenschwander LF (1980) Broadcast burning of sagebrush in the winter. Journal of Range Management 33, 233-236.

Pickford S, Suharti M, Wibowo A (1992) A note on fuelbeds and fire behavior in Alang-alang (Imperata clylindrica). International Journal of Wildland Fire 2, 41-46.

Rothermel RC (1972) A mathematical model for predicting fire spread in wildland fuels. USDA Forest Service, Intermountain Forest and Range Experiment Station, Research Paper INT-115. (Ogden, UT)

Rothermel RC (1991) Predicting behavior and size of crown fires in the Northern Rocky Mountains. USDA Forest Service, Intermountain Research Station, Research Paper INT-438. (Ogden, UT) 
Sapsis DB, Kauffman JB (1991) Fuel consumption and fire behaviour associated with prescribed fire in sagebrush ecosystems. Northwest Science 65, 173-179.

Schaaf MD, Sandberg DV, Schreuder MD, Riccardi CL (2007) A conceptual framework for ranking crown fire potential in wildland fuelbeds. Canadian Journal of Forest Research 37, 2464-2478.

Schimmel J, Granström A (1997) Fuel succession and fire behaviour in the Swedish boreal forest. Canadian Journal of Forest Research 27, 1207-1216.

Scott AC, Bowman DMJS, Bond WJ, Pyne SJ, Alexander ME (2014) 'Fire on Earth: An Introduction'. (Wiley-Blackwell: Chichester)

Stocks BJ, Alexander ME, Wotton BM, Stefner CN, Flannigan MD, Taylor SW, Lavoie N, Mason JA, Hartley GR, Maffey ME, Dalrymple GN, Blake TW, Cruz MG, Lanoville RA (2004) Crown fire behaviour in a northern jack pine - black spruce forest. Canadian Journal of Forest Research 34, $1548-1560$.

Van Wagner CE (1977) Conditions for the start and spread of crown fire. Canadian Journal of Forest Research 7, 23-34.

Van Wagner CE (1985) Fire behavior modelling - how to blend art and science. In 'Proceedings of the Eighth Conference on Fire and Forest Meteorology', 29 April-2 May 1985, Detroit, MI. (Eds LR Donoghue, RE Martin) Society of American Foresters, SAF Publication 85-04, pp. 3-5. (Bethesda, MD)

Weise DR, Biging GS (1997) A qualitative comparison of fire spread models incorporating wind and slope effects. Forest Science 43, 170-180.

Weise DR, Fujioka FM (1998) Comparison of fire spread estimates using weather station observations versus nested spectral model gridded weather. In 'Preprint Volume of the Second Symposium on Fire and Forest Meteorology', 11-16 January 1998, Phoenix, AZ. pp. 75-79. (American Meteorological Society: Boston, MA)

Willmott CJ (1982) Some comments on the evaluation of model performance. Bulletin of American Meteorological Society 63, 1309-1313.

Woodall CA (1998) Prescribed fire behavior and custom fuel modeling in the pitch pine-scrub oak barrens and pine-oak forests of New England. University of Massachusetts, Department of Forestry and Wildlife Management, Course FOREST 698 Report. (Amherst, MA) Available at:

http://www.umass.edu/nebarrensfuels/publications/pdfs/claiborne_woodall.pdf 